\title{
Jefferson, Hip-Hop, and the Oppressive Grid
}

\author{
SEKOU COOKE \\ NADIA M. ANDERSON \\ Syracuse University \\ University of North Carolina at Charlotte
}

Post-Modernist juggernauts, "The New York Five" (Peter Eisenman, Michael Graves, Charles Gwathmey, John Hejduk, and Richard Meier), captured the attention of architectural theorists for many years after the CASE group (Conference of Architects for the Study of the Environment) first discussed their work at the Museum of Modern Art in 1969. Their redirection of the functionalism introduced by early Modernist a half-century before, toward more formalist methods of producing architecture, dominated discourse within the discipline for the rest of the 1900s. Extensive use of purist geometries and surface materials earned them, and others exuding similar operational tendencies (including Colin Rowe and Kenneth Frampton), the nickname "The Whites," setting off a pseudo-rivalry with other less puritanical practitioners, such as Robert Venturi, Robert Stern, and Vincent Scully, contrastingly dubbed "The Grays." Debates about their ideologies and methodologies were so compelling that another half-century later theorists like Emanuela Giudice continue to reference them. Giudice's admission that "the debate that elapsed between the "Whites" and "Grays" showed the need to re-establish ... a discipline devoid of identity..." is the most damning indictment of the entire Post-Modern movement.

This argument assumes that removing identity would result in a more evolved architectural expression and that design, in practice and theory, can and should be ethically neutral. As artist and architectural educator Amanda Williams puts it, "I was always so offended when they talked about them as if it had nothing to do with race." 2 For Williams, any conversation about the "Whites" and "Grays" was incomplete without asking about "The Blacks." 3 To suggest that architecture can be neutral negates that it has any connection to race, gender, wealth, or anything that builds power into the physical environment. This suggestion, according to Dutton and Mann, is completely false. "Architecture... as discourse, discipline, and form, operates at the intersection of power, relations of production, culture, and representation and is instrumental to the construction of our identities and our differences, to shaping how we know the world." ${ }^{\text {4 }}$ We discuss here how architectural methods, as demonstrated by the use of supposedly benign grids, expose how biased values become part of our constructed reality.
The history of the grid as a design and planning tool extends from ancient civilizations across the world to iconic examples from recent history such as Barcelona and Manhattan. The grid has been, however, an especially dominant symbol of power in North America, as demonstrated by the Land Ordinance of 1785 and subsequent ordinances regarding the division of land into private property in the U.S. ${ }^{5}$ As Gabrielle Esperdy argues, "The grid was platted both east and west of the Mississippi not only to exert rigid order and disciplinary control over the chaos of nature, but to claim territory for the newly formed nation." ${ }^{\prime \prime}$ It "firmly established a system of land tenure, land acquisition and government"7 according to mathematical principles grounded in a Cartesian system of principal meridians and baselines. Browsing aerial photographs of the American Midwest, flipping through the pages of James Corner's Taking Measures Across the American Landscape, or simply looking out the window during a transcontinental flight reveal the grid's visible prominence (Figure 1).

Thomas Jefferson, typically credited with creating the U.S. Public Land Survey System (Figure 2), placed such faith in the power of the grid that he used it to organize not only building plans and city streets, but also entire western territories after the Revolutionary War. As a central figure in the American Enlightenment, Jefferson believed as much in its affirmed dominion of scientific reason 'nature as in its core

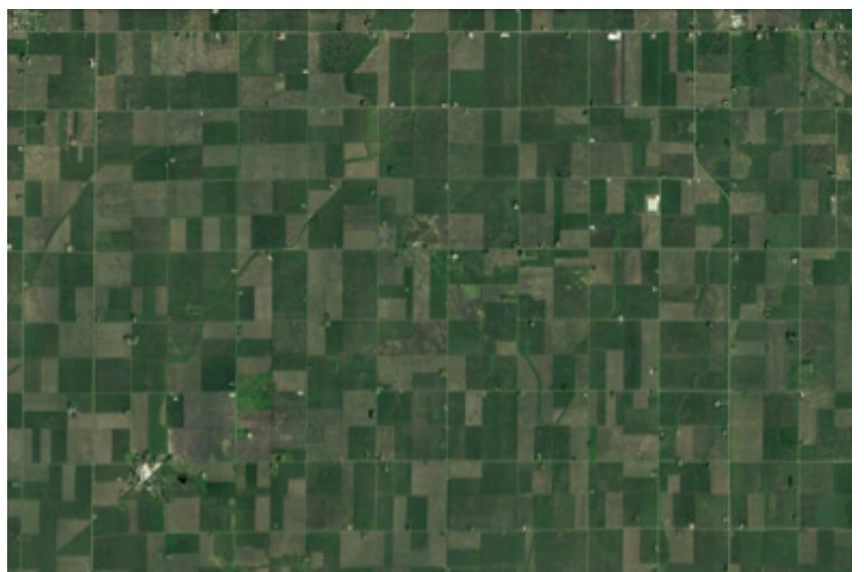

Figure 1. Iowa Aerial Image. Source: Google Earth, $42^{\circ} 59^{\prime} 47.22^{\prime \prime} \mathrm{N}$ and $93^{\circ} 52^{\prime} 30.87^{\prime \prime}$ W, 6/18/16, accessed 9/30/17 


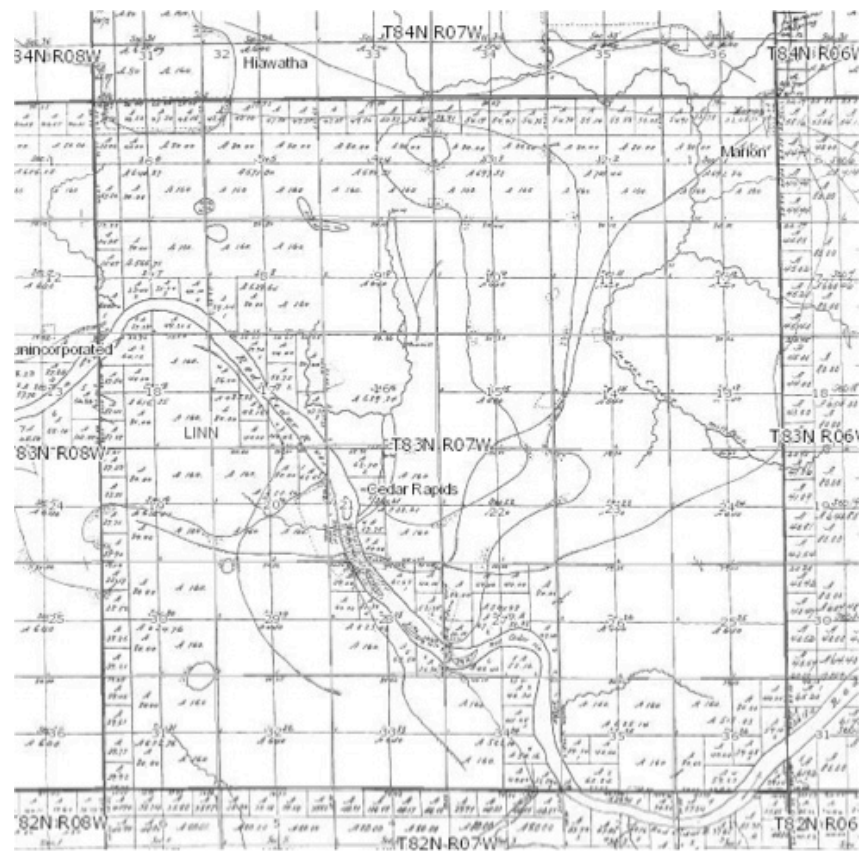

Figure 2. Linn County, General Land Office Survey 1836-1859. Source: Iowa Geographic Map Server, http://ortho.gis.iastate. edu/client_pls.cgi $? z 00 \mathrm{~m}=900 \& \times 0=469163 \& y 0=4653689 \&$ layer $=\mathrm{g}$ lo_survey\&pwidth=600\&pheight=450, accessed 9/30/17.

tenets of democracy and individuality. This included dominion over peoples most closely identified with nature, such as Black slaves, Native Americans, and women. In keeping with what Joel Kovarsky describes as "The story of colonial America," Jefferson saw the land to the west of the original thirteen states (and its inhabitants) in terms of "geography and empire, land and landscape, and control and measurement." ${ }^{8}$ Similarly, Irene Cheng, in writing about Jefferson's tendency towards geometries such as octagonal building and garden plans, notes, "architectural features traditionally read as race-neutral are inextricably entangled with issues of race and slavery." 9 She further ties this to his Enlightenment ideals by concluding, "the black subject's supposed incapacity for reason and aesthetic imagination haunted the geometric clarity of Jefferson's eight-sided architectural forms." ${ }^{10}$ The discovery that Jefferson himself owned slaves reinforces the link between his geometric preferences and his need to exert control other humans (as he would with any other property). His allegiance to grids, and other forms of Euclidian geometry, as used for spatial delineation and measurement of human beings and land as productive capital, illustrates the oppressive potentials of these tools.

Repercussions of biases within these systems of the past extend into political, economic, and spatial conditions of power in the present. According to the study The Racial Wealth Gap conducted by Demos and Brandeis University's Institute for Assets and Social Policy, "in 2011 the median White household had $\$ 111,146$ in wealth holdings, compared to just $\$ 7,113$ for the median Black household and
$\$ 8,348$ for the median Latino household."11 Differing rates of homeownership and property values that vary by racially segregated neighborhoods are among the largest contributors to this gap. Households that own property can build equity, ultimately passing this down to their children, while neighborhoods with higher property values tend to have better schools and better quality services. Much of the legacy of these disparities is rooted in property ownership policies that translate the bias toward the virtuous (White, male) "yeoman farmer" of Jefferson's grid into an underlying moral power bias in favor of Whites. Patterns created by the National Housing Act of 1934 continue to persist long after the outlaw of "redlining" in 1968. Discriminatory lending, higher rates of personal debt, and gentrification all contribute to the rising home-ownership gap between Whites and people of color.

When viewed holistically, the shared history of Black people in America and the Jeffersonian grid is a markedly contentious one. Mos Def (a.k.a. Yasiin Bey), in rapping about a fabric's pattern, artfully summarizes this relationship in his track, A Soldier's Dream:

If you look closer, you'll notice that this pattern resembles Tenement row houses, project high-rises, cell block tiers Discontinued stretches of elevated train tracks Slave ship gullies, acres of tombstones ${ }^{12}$

Each item on Def's list is a reminder a four-hundred-year hardship. From the moment Blacks were packed onto slave ships they were met with prevalent systems of neutrality, order, and efficiency. They rebelled. Later, housed in tightly confined slave quarters and shotgun houses, they rebelled. More recently, relegated to public housing, public schools, and private prisons, each with spatial logics and security features (bars on windows, chain-link fences, etc.) exemplifying hyper-rationality and utility, they rebelled. Though the grid itself cannot bear responsibility for each oppressive act, its legibility within the forms listed above belies the assumed neutrality of its existence. Architectural historian, Lawrence Chua, who analyses A Soldier's Dream in his chapter on hip-hop's Utopian aspirations, helps to connect this latest rebellion to the cultural production of the South Bronx in the early 1970 s. $^{13}$

This connection was somehow lost on "The New York Five" and their cohorts at the Institute for Architecture and Urban Studies $^{14}$ whose Manhattan-based program existed in virtual concurrence with hip-hop's rise. While they were congratulating themselves for ushering a new era of architectural research and practice, grounded in an appreciation for history and theory, they were completely oblivious of (or willfully ignorant to) the cultural genesis happening a hundred blocks to the north. Their adherence to the grid as a primary formal and organization device reflected on Modernist masters, including Mies van der Rohe, Le Corbusier, and Adolf 


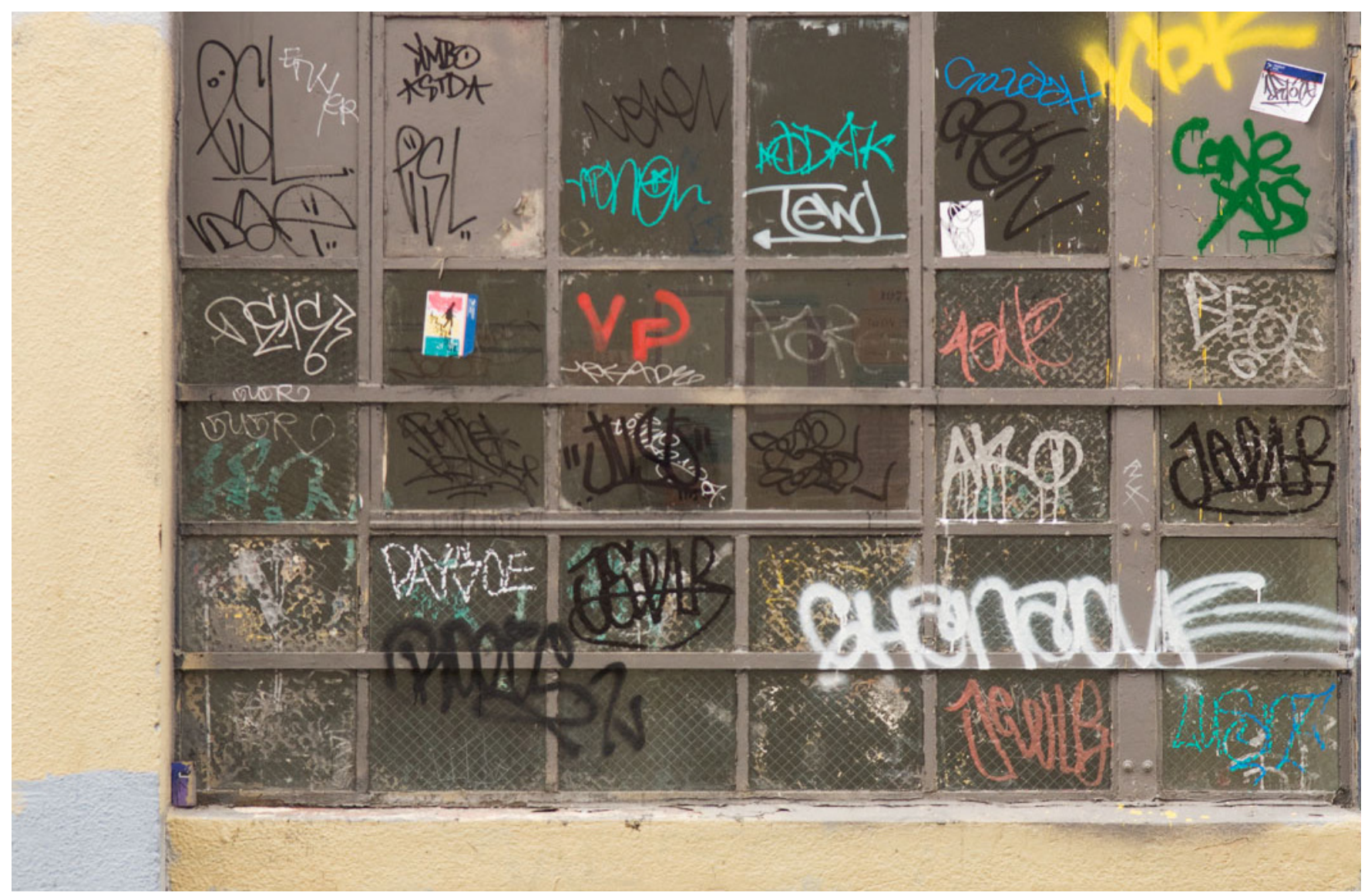

Figure 3. Andrew Schneider, "Graffiti Grid"

Loos, whose celebration of architecture's mechanical attributes and condemnation of ornament was derived from the same Enlightenment principles espoused by Jefferson. In his essay "Ornament and Crime," Loos, for example, associates the elimination of ornament in favor of efficiency and utility as a feature of morally superior cultures. He further conflates ornament not only with degeneracy and criminality but also with "the Kaffir, the Persian," (translation: people of color) and "the Slovak peasant woman." ${ }^{15}$ Rafael Schacter, in making the argument for graffiti (or Independent Public Art, as he calls it) as architectural ornament, states, "For Loos and his many followers decorative form in its entirety was ripe for extinction, representing 'backwardness or even a degenerative tendency, ${ }^{\prime \prime 16}$ reaffirming the elitist slant of Modernist philosophies. Hip-hop culture-often unfairly reduced to degeneracy and criminality itself-presents a viable counterpoint to Loos.

As introduced in "The Fifth Pillar: A Case for Hip-Hop Architecture," hip-hop culture can be seen as a direct response of Black and Latino youth to the oppressive nature of gridded Modernist environments. ${ }^{17}$ Hip-hop's pioneers (mostly high-school students without access to proper art, dance, or music education) developed their own defiant forms of artistic expression against a backdrop of the ubiquitous grid. This defiance takes on a disparate form from that categorized as "decongestion" in Esperdy's reading of Rem Koolhaas' Delirious New York. Instead of consolidating city grids into "superblocks...the ultimate grid-defying weapon,"18 deejays, emcees, b-boys, and graf writers envisioned a world completely independent of the grid-a space of breaks, scratches, and flows. Grid-laden concrete surfaces became canvasses for tags, throw-ups, and pieces, (figure 3 ) or stages for breaking, popping, and locking. Pure whites and grays were shunned for neon pinks, yellows, and lime greens, or for cross colors in black, red, green, and gold. Hip-hop culture provides a welcome antithesis to the grid's legacy and holds the power to co-opt architecture from its affluent, White, male figureheads who continue to profess neutrality and universality.

Neutrality in architecture depends on its definition as a service provided by professionals only to those "who can afford to pay professional fees and who receive, in exchange, highly customized responses to their specific needs." ${ }^{19}$ This system perpetuates the shaping of the built environment around values that give power to those with financial capital. It assumes that those with exclusive professional knowledge coupled with material wealth has the right to determine the experience of all others. As the grids of American cities and cities around the world fill with luxury apartments and extravagant houses (while millions lack adequate housing) 
the contemporary results of Jefferson's grid, transforming land and people into capital for production and consumption, are revealed.

With increased focus being placed on glaringly low representation statistics within the architectural profession, diversity has gained marginal ground as a topic of discussion within architecture schools and organizations. Once understood solely as a way of bringing established architectural thought to the masses-a thought process echoing the oppressive mindset of Jeffersonian Enlightenment-diversity is now recognized as a means for expanding architectural thought and increasing disciplinary relevance through the addition of minority voices. "The valuing of the production of space by all people... [can thus] provide a framework for architecture to effectively address contemporary issues such as poverty [and] homelessness... by focusing on the social systems that created these conditions and providing alternatives connected to existing social practices."20 However, if architecture continues to perpetuate the false assumption that its most basic tools are neutral, it will fail to address its malignant lack of diversity, and remain mired in rhetorical comparisons between subtle shades of gray.

\section{ENDNOTES}

1 Emanuela Guidice, "L'architettura tra 'Whites" e "Grays.' Strumenti, metodi e applicazioni compositive," in FAmagazine 30, (November-December 2014): 24, 25.

2 Amanda Williams, speaking at Towards A Hip-Hop Architecture symposium, Syracuse, NY: 20 March 2015, (transcript unpublished).

3 Ibid.

4 Thomas A. Dutton and Lian Hurst Mann, "Introduction," in Reconstructing Architecture: Critical Discourses and Social Practices, eds. Thomas A. Dutton and Lian Hurst Mann, (Minneapolis: University of Minnesota press, 1996), 1.

5 For the text of the Land Ordinance of 1785 and history of its development, along with subsequent ordinances, see C. Albert White, A History of the Rectangular Survey System, U.S. Department of the Interior and Land Management, 1983.

6 Gabrielle Esperdy, "Defying the Grid: A Retroactive Manifesto for the Culture of Decongestion," in Perspecta, Vol. 30, (1999): 11, 12.

7 White, 16

8 Joel Kovarsky, The True Geography of Our Country: Jefferson's Cartographic Vision (Charlottesville, VA: University of Virginia Press, 2014), 9.

9 Irene Cheng, "Race and Architectural Geometry: Thomas Jefferson's Octagons," in J19: The Journal of Nineteenth-Century Americanists, Vol 3, No. 1, (2015): 129

10 Ibid.

11 Amy Traub, Catherine Ruetschlin, The Racial Wealth Gap: Why Policy Matters, June 21, 2016, accessed September 27, 2017, http://www.demos.org/ publication/racial-wealth-gap-why-policy-matters.

12 Lyrics here are as transcribed on www.genius.com.

13 Lawrence Chua, "Life in Marvelous Times: Hip-hop, Housing, and Utopia," Archi.pop: Mediating Architecture and Culture, ed. D. Medina Lasansky, (New York: Bloomsbury Academic, 2015), 205.

14 The story of the short-lived Institute (IAUS), founded by Eisenman, is the subject of an undistributed 2013 documentary, The Making of an Avant-Garde: The Institute for Architecture and Urban Studies 1967-1984, by Diana Agrest, that highlights the aloof nature of work done by "The New York Five," fully invested in creating new knowledge based in formalism and separated from the political and social realities of a city in decline.

15 Adolph Loos, "Ornament and Crime" in Programs and Manifestoes on 20th century Architecture, ed. Ulrich Conrads (Cambridge, MA: The MIT Press, 1971), 19-24.
16 Raphael Schacter, Ornament and Order: Graffiti, Street Art and the Parergon, (Farnham, UK: Ashgate, 2016), 30.

17 Sekou Cooke, "The Fifth Pillar: A Case for Hip-Hop Architecture", Harvard Journal of African American Public Policy, (2014).

18 Esperdy, 13.

19 Thomas Fisher, "Public-Interest Architecture: A Needed and Inevitable Change," in Expanding Architecture: Design as Activism, eds. Bryan Bell and Katie Wakeford (New York: Metropolis Books, 2008), 9.

20 Nadia M. Anderson, "Public Interest Design as Practice," Journal of Architectural Education, 68:1 (2014): 17. 